\title{
Kronik bel ve boyun ağrılı hastada temel analjezikler
}

\author{
Basic analgesics in patients with chronic neck and low back pain
}

\author{
Mehmet Eroğlu, Sibel Eyigör
}

Ege Üniversitesi Tıp Fakültesi Fiziksel Tıp ve Rehabilitasyon Anabilim Dalı, Bornova, İzmir

\begin{abstract}
Kronik bel ve boyun ağrıları toplumda yaygın olarak görülmekte, aktivite kısıtlılığı ve iş gücü kaybına yol açmaktadır. Non-steroidal anti-inflamatuvar (NSAi) ilaçlar ve asetaminofen ise birçok ağrılı durumun tedavisinde ilk seçenek olarak kullanılmaktadır. Ancak, bu ilaçların kronik boyun ve bel ağrılarında etkinliği ve güvenirlikleri net değildir. Bu ilaçların etki mekanizmaları da halen tam olarak aydınlatılamamıştır. Bu derlemede; parasetamol ve NSAi ilaçların etki mekanizmaları, kronik boyun ve bel ağrısı tedavisindeki yerleri ve yan etki profillerindeki güncellemeler incelenmeye çalışılmıştır.
\end{abstract}

Anahtar sözcülkler: ağrı; parasetamol; non-steroidal antiinflamatuvar; bel; boyun
Chronic neck and low back pain are common in the society, leading to activity limitation and labor loss. Non-steroidal anti-inflammatory (NSAI) drugs and acetaminophen are used as the first option in the treatment of many painful conditions. However, the efficacy and safety of these drugs in chronic neck and low back pain is not clear. The mechanisms of action of these drugs are still unclear. In this article, the mechanisms of action of NSAI drugs and paracetamol, their usage at chronic neck and low back pain treatment, and the side effect profiles are reviewed.

Key words: pain; paracetamol; non-steroidal anti-inflammatory; low back; neck
K ronik boyun ve bel ağrıları, toplumda önemli ölçüde engellilik ve iş gücü kaybına neden olan, aynı zamanda ciddi ekonomik kayıplara yol açan durumlardır. ${ }^{[1]} \mathrm{Bu}$ ağrıların yönetiminde egzersiz, davranışsal terapi, alternatif tıp ve cerrahi müdahale gibi yöntemler uygulansa da, farmakolojik tedaviler en sık önerilen ve kullanılan yöntemlerdir. ${ }^{[2]}$ Non-steroid anti-inflamatuvar (NSAi) ilaçlar, opioidler ve kas gevşeticiler, boyun ve bel ağrılarında en çok reçete edilen ilaçlardır. Ancak, kronik boyun ve bel ağrılarında kas gevşetici ajanların herhangi bir etkinliği gösterilememiştir. Bu nedenle, kronik bel boyun ağrılarında kullanılan temel ajanlar, NSAi ilaçlar olarak görülmektedir. ${ }^{[3]}$ Opioid ve adjuvan ilaçlar ise bu derlemenin dışında tutulmuştur.

\section{NON-STEROID ANTi-iNFLAMATUVAR ILAÇLAR}

NSAi ilaçlar, akut ağrılar, cerrahi sonrası ağrılar ve romatizmal hastalıklar, osteoartrit, kronik bel boyun ağrıları gibi birçok klinik tablonun yönetiminde tedavinin temel taşıdır. ${ }^{[4]}$ Etkili bir analjezi sağlaması, geniş spektrumu, görece ucuz ve erişilmelerinin kolay olması gibi nedenlerle toplumda çok yaygın olarak kullanılır. Alttmış beş yaş üstü popülasyonun \%70'inin haftada en az bir, \%35'inin ise en az yedi doz NSAi ilaç kullandığı belirtilmektedir. ${ }^{[5]}$ NSAi ilaçlar çoğunlukla analjezik, antipiretik, anti-inflamatuvar etkilere sahiptir. ${ }^{[6]}$ Bu grup ilaçların bazılarının analjezik etkileri, bazılarının anti-inflamatuvar etkileri ön planda iken, bir kısmında iki etki de dengeli olarak görülür. ${ }^{[7]}$

\section{SINIFLANDIRMA}

NSAi ilaçlar, kimyasal yapılarına, siklooksijenazCOX enzimleri ile olan ilişkilerine ve plazma yarılanma sürelerine göre farklı sınıflamalara tabidir (Şekil 1). ${ }^{[8]}$ Aspirin, COX enzimini geri dönüşümsüz inhibe etme$\mathrm{si}$, asetaminofen ise in vivo anti-inflamatuvar etkiden yoksunluğu nedeniyle, bazı kaynaklarda klasik sınıflandırmaların dışında tutulur.

- Illetişim adresi: Prof. Dr. Sibel Eyigör, Ege Üniversitesi Tıp Fakültesi Fiziksel Tıp ve Rehabilitasyon Anabilim Dalı, Bornova, İzmir Tel: 0232 -3903687 e-posta: eyigor@hotmail.com

- Geliş tarihi: 20 Șubat 2017 Kabul tarihi: 20 Şubat 2017 


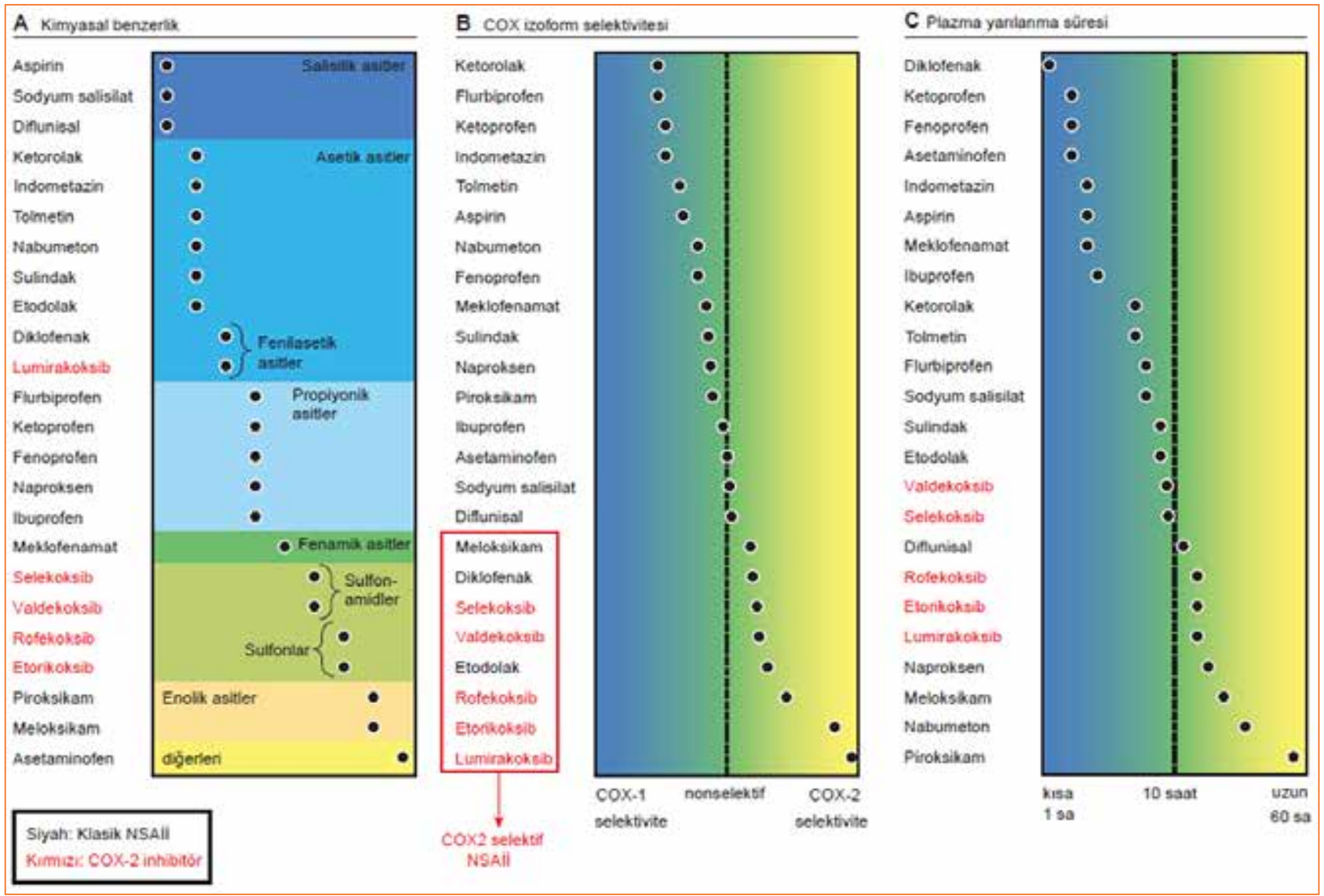

Şekil 1. NSAi ilaçların farklı sınıflamaları.

\section{Etki Mekanizması}

İnflamasyonda, COX ve lipooksijenaz enzimatik yolakları etkindir. COX enziminin NSAi ilaçlar ile inhibisyonu yoluyla, prostoglandin sentezi inhibe edilir. Inflamasyonun önlenmesinde, klasik NSAi ilaçların temel etkisi COX inhibisyonudur. ${ }^{[9]}$

Yakın zamana kadar, siklooksijenazın yapısal ve indüklenebilir (COX-1 ve COX-2) olarak iki formu olduğu kabul edilmekteydi. Ancak yeni çalışmalarda, bir COX-3 izoformundan da söz edilmektedir. COX-1; damar endoteli, trombositler, mide mukozası, ve böbrek tübülleri gibi birçok hücrede homeostazda önemli yeri olan izoenzimdir. Fizyolojik durumlarda, COX-1 aktif durumdadır ve fizyolojik cevapları düzenleyen prostoglandinlerin üretiminde görev alır. İndüklenebilir siklooksijenaz COX-2 ise fizyolojik koşullarda dokularda bulunmaz; ancak, inflamasyon varlığında dokularda indüklenir ve inflamasyona yanıt olarak üretilir. COX2 , inflamasyon, ağrı ve ateş yanıtını sağlayan prostoglandinlerin üretiminde görev alır. NSAi ilaçlar, etki ve yan etkilerini bu enzimleri inhibe ederek gösterir. NSAi ilaçların çoğu, hem COX-1 hem de COX-2'yi farklı oranlarda inhibe eder. Bu yüzden, hem istenen hem de istenmeyen etkiler farklı düzeylerde görülür. Özellikle COX-1 inhibisyonu ile, gastrik epitelyal hücrelerden sitoprotektif prostoglandinler salınamamakta ve klasik NSAi ilaçlara ait gastrointestinal sistem (GiS) yan etkileri açığa çıkmaktadır. COX-2 selektif NSAi ilaçlar, COX-2 enzimini COX-1'e göre yüksek oranda inhibe etmekte, yine doz arttıkça COX-1 inhibisyonu da artmaktadır. Bu nedenle, COX-1 inhibisyonu ilişkili yan etkilerden kaçınmak amacıyla, COX-2 spesifik NSAi ilaçlar geliştirilmiştir. ${ }^{[10]} \mathrm{Bu}$ grubun üretilmesindeki amaç, Gis, renal ve endotel fonksiyonlarını etkilemeden analjezik etki sağlamak olmuştur. Ancak, yapılan çalışmalarda kardiyak yan etkiler saptanmış ve bu gruptan bazı ilaçlar (rofekoksib, valdekoksib) piyasadan çekilmiştir. ${ }^{[6,8]}$ COX-3 izoenziminin bulunması ve sonrasında fare beyni ve insan dokularında varlığının gösterilmesi ile, zayıf COX-1 ve COX-2 inhibisyonu yapan bazı NSAi ilaçların ve özellikle asetaminofenin etki mekanizmasında bu enzimin inhibisyonun önemli bir yer tutabileceği öne sürülmüştür. Asetaminofen ve 
NSAi ilaçların santral sinir sistemi (SSS)'ne geçerek burada COX-3 inhibisyonu yaptıkları ve bu sayede santral analjezik ve antipiretik etki gösterdikleri düşünülmüştür. [11] Ancak, COX-3 izoenziminin COX-1'in bir varyantı olduğu ve NSAi ilaçlar ve asteminofenin analjezik etkinliğinde temel rolü oluşturmadığını bildiren çalışmalar da mevcuttur. ${ }^{[12]}$ Bu alanda yapılacak yeni çalışmalara ihtiyaç duyulmaktadır.

\section{ABSORPSIYON, DAĞILIM, ELIMINASYON}

Çoğu NSAi ilaç, oral alımı takiben hızla emilir ve 2-3 saat içinde maksimum plazma konsantrasyonuna ulaşır. Gıdalarla birlikte alındıklarında emilimleri gecikebilir ve fenoprofen, sulindak gibi bazılarının sistemik yararlanımı azalabilir. Diklofenak, nabumeton gibi bazı bileşikler ise ilk geçişte veya presistemik eliminasyona uğrar.

Çoğu NSAi ilaç, plazma proteinlere yüksek oranda bağlanır (\%95-99). Bu yüzden, plazma protein konsantrasyonunun değiştiği durumlar ya da NSAi ilaçlarla aynı protein bölgelerine affinite gösteren diğer ilaçlar, plazma serbest NSAi ilaç düzeyini arttırarak toksik etkilere yol açabilir. Çoğu NSAi ilaç vücutta geniş bir dağılım gösterir; SSS'ye santral bir analjezi gösterecek düzeyde geçer. Selekoksib ise, lipofilik özelliği sayesinde, SSS'ye kolayca taşınır.

NSAi ilaçların plazma yarılanma ömürleri $(\mathrm{t} 1 / 2)$ ise oldukça değişkenlik gösterir. Örneğin, ibuprofen ve diklofenak için $\mathrm{t} 1 / 2$ 1-4 saat iken piroksikam için bu süre yaklaşık 50 saattir. Hepatik biyotransformasyon ve renal itrah, çoğu NSAi ilacın temel eliminasyon yoludur. ${ }^{[8]}$

\section{Analjezik Etkileri}

Önceleri, NSAi ilaçların periferik nosiseptif cevapları modüle ederek analjezi sağladığı düşünülürdü. Ancak, çalışmalar santral ve periferik şeklinde iki tür etkinin olduğunu göstermiştir. ${ }^{[13]}$ Periferik etkilerini; siklooksijenaz ve lipooksijenaz yolakları sonucu üretilen prostoglandin ve lökotrienlerin inhibisyonu ile sağlar. ${ }^{[14]}$ Santral olarak ise; spinal yolaklarda $\mathrm{P}$ maddesi ve N-metil-D-aspartik asit (NMDA), oluşturduğu hiperaljeziyi inhibe eder. Santral COX enzimleri tarafından üretilen prostoglandinlerin, ağrının santral iletim mekanizmalarında da rol aldığı, eksitatuvar bir nörotransmitter olan glutamat oluşumunu indüklediği gösterilmiştir. NSAi ilaçlar, santral sinir sisteminde opioid ilişkili noradrenerjik yolaklarda prostoglandin sentez inhibisyonu yapar. Yine, opioid/NSAi ilaç kombinasyonlarının allodiniyi inhibe etmede sinerjistik etki gösterdiği bildirilmiştir. ${ }^{[15]}$ Ayrıca, diklofenakın analjezik etkisinin naloksan ile antagonize edilebildiği ve opioid bağımlılarında diklofenakın yoksunluk belirtilerini azalttığı gösterilmiştir. Bu bilgiler, NSAi ilaçların santral opioid mekanizmaları aracılığıyla da etki gösterdiğini düşündürmüştür. ${ }^{[16]}$ Hayvan modellerinde, hipotalamus, ve periakuaduktal gri cevherde NSAi ilaçların etki bölgelerinin varlığı gösterilmiştir. Yine, NSAi ilaçların NO (nitrik oksit) ve serotonin yolakları üzerinde etkili olduğu da gösterilmiştir.[17]

\section{YAN ETKILERi}

\section{Gastrointestinal Sistem}

NSAi ilaçlar, gastrointestinal sistemin hemen her yerinde toksik etkiler gösterebilir. Ancak en sık, mide ve duodenum ülserleri ile buna bağlı olarak gelişen kanama, perforasyon gibi komplikasyonlar görülür. [18] NSAi ilaçlara bağlı gelişen gastrik lezyonlar asemptomatik de olabilir. NSAi ilaçlarla üç ay tedavi alanlarda, yeni gelişen duodenal ve mide ülseri sıklığının \%4-15, gastrik ülser sıklığının ise \%10-40 arasında olduğu, endoskopik çalışmalarla saptanmıştır. ${ }^{[19]}$ Bir sistematik derlemede ise NSAi ilaç alan hastalarda H.pylori pozitif olanların ülser sıklığı, negatif olanların 17,5 katı bulunmuştur. ${ }^{[20]}$ Maastricht III konsensüsünde; H.pylori eradikasyonu, kronik NSAi ilaç kullanan hastalarda önemli olsa da, tedaviye proton pompa inhibitörü eklenmesinin H.pylori eradikasyonundan üstün olduğu belirtilmiştir. ${ }^{[21]}$

\section{Karaciğer}

NSAi ilaç kullanımına bağlı olarak, karaciğer enzimlerinde hafif yükselme görülebilir. Karaciğer hasarı oldukça nadirdir. Karaciğer enzim düzeyinde normalin üç katından fazla artış olması durumunda ilaç alımı kesilmelidir. Yapılan araştırmalarda, fenilbutazon, diklofenak ve sulindak ile karaciğer toksisitesi daha sık saptanırken, ibuprofen ve ketoprofenle görece daha az bildirilmiştir. ${ }^{[22]}$ Bir derleme de ise, selekoksibin karaciğer yan etkileri plasebo, ibuprofen ve naproksene benzer ve diklofenakdan daha az bulunmuştur. ${ }^{[23]}$

\section{Böbrekler}

NSAi ilaçların böbrekler üzerine oldukça önemli yan etkileri mevcuttur. Akut interstisiyel nefrit, renal hipoperfüzyon ve buna bağlı akut böbrek yetmezliği görülebilir. Özellikle renal perfüzyonun az olduğu durumlarda, akut böbrek yetmezliği riskini oldukça artar. $\mathrm{Bu}$ nedenle, kalp yetmezliği, hipovolemi ve siroz gibi durumlarda kullanımlarından kaçınılmalıdır. ${ }^{[5]}$ Kronik kullanımlarda ise, kronik tübülointerstisiyel nefrit, analjezik nefropatisi ve buna bağlı kronik böbrek yetmezliği gelişebilir. ${ }^{[24,25]}$ Analjezik nefropatisi gelişen hastalarda tüm NSAi ilaçlar bırakılmalıdır. 


\section{Pulmoner Yan Etkiler ve Anafilaksi}

Astım nöbetleri, bronkospazm anaflaktik şok, anjiyoödem görülebilir. ${ }^{[26]}$

\section{Cilt}

Akut ürtiker, kronik ürtiker alevlenmesi, eritema nodozum, ilaç bağı ı̈öküntüler ve Stevens-Johnson sendromu gibi etkiler gelişebilir. ${ }^{[27]}$

\section{Santral Sinir Sistemi}

Psikoz ve kognitif bozukluk, aseptik menenjit gelişimine neden olabilir. Özellikle indometazin ile; tinnitus, işitme kaybı, vertigo, baş ağrısı, konfüzyon, uyku bozukluğu gibi yan etkiler oluşabilir. ${ }^{[28]}$

\section{Kardiyovasküler Sistem}

NSAi ilaçlara bağlı olarak, kan basıncında yükselme ve mevcut kalp yetmezliğinde kötüleşme görülebilir. Aspirinin, geri dönüşümsüz COX inhibisyonu yoluyla kanama zamanını uzattığı ve kardiyovasküler olay insidansını azalttığı bilinmektedir. Ancak, düşük dozda dahi olsa, GiS'te kanama riski oluşturduğu gösterilmiştir. Ancak, çoğu NSAi ilaç bu kardiyoprotektif etkiden yoksundur. Hatta, düşük doz aspirin ile ibuprofen kombinasyonunda dahi aspirinin kardiyoprotektif etkisi kaybolmaktadır. Bu durumun istisnası ise kardiyak açıdan nötr kabul edilen naproksendir. ${ }^{[8]}$ Epidomiyolojik çalışmalarda, naproksenin miyokard infarktüsünde \%10 kadar azalma sağladığı bildirilse de, aspirinin yerine kardiyoprotektif amaçla kullanılamaz. Kalp yetmezliği açısından ise naproksen; COX-2 inhibitörleri ve ibuprofenden az olsa da diklofenakla yakın düzeyde riskli bulunmuştur. ${ }^{[29]}$

Spesifik COX-2 inhibitörleri olan selekoksib, valdekoksib ve rofekoksible yapılan plasebo kontrollü çalışmalarda, miyokard enfarktüs ve trombotik olay gelişim riskinde artış gözlenmiş ve valdekoksib ile rofekoksib piyasadan çekilmiştir. Yine, klasik NSAi ilaçlardan diklofenak, nimesulid, meloksikam gibi COX-2 selektivitesi fazla olan bileşiklerin de kardiyovasküler riskleri olduğu gösterilmiştir. Özellikle doz bağımlı olarak, tüm NSAi ilaçların kalp yetmezliği ve miyokard enfarktüsü riskini arttırdığı bildirilmiştir. Buna bağlı olarak, ABD ve $A B$ 'deki düzenleyici kuruluşlar, tüm NSAi ilaçların kalp krizi ve inme riskini arttırabileceğini belirtmişlerdir. $^{[5,30]}$ Bu nedenle, akut miyokard infarktüsünde, unstabil anjina pektoris ve kalp yetmezliği durumlarında, NSAii tedavisinden kaçınılmalıdır. ${ }^{[31,32]}$ Kalp yetmezliği dışında kardiyovasküler açıdan ise, kullanımın zorunlu olduğu hallerde en güvenilir ajan naproksen olarak görülmektedir.

\section{PARA-AMINOFENOL TÜREVLERI (ASETAMINOFEN)}

Asetaminofen (parasetamol; $\mathrm{N}$-asetil-p-aminofenol) fenasetinin aktif metabolitidir. Yüz yıldan fazla bir süredir analjezik ve anti-piretik olarak kullanılmaktadır. Asetaminofen, ağrılı uyarana karşı eşik değerini yükselterek farklı ağrı etiyolojilerinde analjezik etkinlik sağlar. Narkotik ve narkotik olmayan diğer analjeziklerle, barbitüratlarla, kafein, kas gevşeticiler ve uyku ilaçlarıyla çeşitli dozlarda kombinasyonları mevcuttur. Analjezik ve anti-piretik olarak diğer NSAi ilaçlara güçlü bir alternatifken, anti-inflamatuvar etkinliği bunlara kıyasla oldukça düşüktür. Bu nedenle, kronik inflamatuvar durumlarda kullanımı kısıtıdır. Asetaminofen iyi tolere edilir ve GiS yan etki insidansı düşüktür. Ancak, akut yüksek doz alımları ciddi karaciğer hasarına neden olabilir. Günlük 2 g'ın altındaki dozların kronik kullanımı, genellikle karaciğer disfonksiyonuna neden olmasa da, özellikle ABD'de asetaminofen-narkotik ilaç kombinasyonlarının aşırı kullanımı karaciğer toksisitesine olan farkındalığı arttırmıştır.

\section{Etki Mekanizması}

Analjezik ve anti-piretik etkinliği aspirine benzer olmasına karşın, anti-inflamatuvar etkinliği düşüktür. Benzer özelikler göstermesine karşın anti-inflamatuvar etkisinin diğer COX inhibitörlerinden zayıf olması, farklı etki mekanizmalarına sahip olduğunu düşündürmüştür. ${ }^{[33,34]}$ İn vitro ortamda ise, sağlıklı gönüllülerin kanında 1000 mg dozun \%50 COX 1 ve 2 inhibisyonuna neden olduğu gösterilmiştir. Yine, COX inhibitörlerinin analjezi sağlamadığı, bazı modellerde etkili olduğu gösterilmiştir. Olası etki mekanizmaları olarak; COX inhibisyonu, $\mathrm{P}$ maddesi, endojen opioid sistemi, serotonin ve NO yolağı üstüne etkisi, kannabinoid reseptörlerine etkisi sayılabilir. ${ }^{[35-37]}$ Asetaminofenin periferde zayıf, santralde ise güçlü prostoglandin inhibisyonu yaptığı belirtilmiştir. ${ }^{[38]}$ Buna neden olarak, periferik inflamasyon alanında bolca bulunan peroksit iyonların varlığında asetaminofenin COX inhibisyonu etkisinin düşük olması gösterilmiştir. ${ }^{[39]}$ Beyinde ise peroksit yoğunluğu daha azdır. Bir diğer görüş ise, asetaminofenin santral sinir sistemine daha kolay geçtiği ve beyinde COX-3 inhibisyonuyla anti-piretik ve analjezik etki sağladığıdır. ${ }^{[40]}$ Buna karşın, COX-3 inhibisyonun asetaminofen etki yolağında bir rolü olmadığına dair de pek çok kanıt sunulmuş olup, hangi COX varyantının asıl etkili olduğu veya bahsedilen diğer yolakların (serotonin vb.) ne derece katkıda bulunduğu henüz netlik kazanmamıştır. ${ }^{[41]}$

\section{Absorpsiyon, Dağılım ve Eliminasyon}

Asetaminofenin oral biyoyararlanımı oldukça yüksektir. Maksimum plazma konsantrasyonuna 30-60 
dk içinde ulaşır ve yarılanma ömrü yaklaşık 2 saattir. Vücut sıvılarında dağılımı görece eşittir. Diğer NSAi ilaçlara göre plazma proteinlere daha az bağlanır. Glukronik asit (\%60), sülfürik asit (\%35) ve sisteinle (\%3) hepatik konjugasyona uğrayarak, terapötik dozlarda tamamına yakını bir gün içinde idrarla atılır. ${ }^{[8]}$

\section{Terapötik Kullanımı}

Asetaminofen, birçok ağrılı durumda ilk tercih ilaçtır. Yine, diğer NSAi ilaçların kontrendike olduğu peptik ülser vb. durumlarda tercih edilmektedir. Amerikan Gıda ve îlaç dairesi (FDA) 2009 yılında yayımladığı önerilerinde, $4 \mathrm{~g}$ /gün olan maksimum dozun ciddi karaciğer hasarı ve ölüme yol açabildiğini belirterek, günlük maksimum dozunun 3000 mg'a, tek seferde alınan maksimum dozunun ise 1000 mg'dan 650 mg'a düşürülmesini tavsiye etmiştir. Yine, tablet, kapsül ve süspansiyonların içeriğinin 325 mg'a düşürülmesi önerilmiştir. Alkolizm, kötü beslenme, genetik risk faktörleri ve ilaç etkileşimleri gibi risk faktörlerini varlığında, hepatotoksisitenin terapötik dozlarda dahi gelişebildiği bildirilmiştir. Bu öneriler ve güncel rehberlere dayanarak, 2011 yılında ABD'deki üretici firma tarafından gönüllü olarak, Tylenol isimli asetaminofen preparatlarının maksimum dozu $3000 \mathrm{mg}$, preparat içerikleri 325 ve $500 \mathrm{mg}$ olarak yeniden düzenlenmiştir.

\section{Yan Etkiler}

Terapötik dozlarda, kardiyovasküler, pulmoner sistem, trombositler ve koagülasyon üzerinde etkisi yoktur. Epidemiyelojik çalışmalarda, Gis yan etkilerinin diğer NSAi ilaçlara göre daha az görüldüğü belirtilmiştir. Nötropeni, pansitopeni, hemolitik anemi, böbrek hasarı gibi etkiler de bildirilmiştir. Karaciğer hasarı ise doz ilişkilidir. Klasik bilgi olarak, 7,5 g üstündeki akut toksikasyonların karaciğer hasarına yol açtığı söylense de, 4 g'ın altındaki dozlarda dahi bu etki görülebilmektedir. En ciddi akut yan etki, fatal karaciğer nekrozudur. Renal tübüler nekroz ve hipoglisemik koma da görülebilir. Glukoronat ve sülfat konjugasyon yolakları doygunluğa eriştikçe, daha fazla miktarda asetaminofen, Cytochrome $\mathrm{P}$ (CYP) aracılı $\mathrm{N}$ hidroksilasyona uğrayarak N-Acetyl-p-benzoquinone imine (NAPQI) metabolitini oluşturur. NAPQI, normalde hızla glutatyonla konjuge edilerek metabolize edilir. Yüksek doz asetaminofen alımında ise, karaciğer glutatyon rezervi hızla tükenir. Reaktif NAPQI metaboliti karaciğerin yapısına ve enzimatik sistemine hasar verir. Yine glutatyonun tükenmesi ile, karaciğer oksidatif streslere ve apopitoza açık hale gelir. CYP enzim sistemini indükleyen (alkolizm vb.) veya glutatyon düzeyini azaltan (malnütrisyon vb.) durumlar karaciğer hasarına duyarlılığı arttırır. ${ }^{[8]}$ Karaciğer hasarında semptomlar ilk iki gün içinde ortaya çıkar. Subkostal ağrı, anoreksi ve karaciğer enzimlerinde yükselme görülür. Renal yetmezlik görülebilir. Enzim düzeyleri 72-96 saatte pik yapar. Ensefalopati ve koagülopati, kötü prognoz göstergesidir. Asetaminofen toksisitesinde, aktif kömür, $\mathrm{N}$-asetil sistein ve agresif destek tedavileri yer alır. $\mathrm{N}$-asetil sistein, NAPQI metabolitini detoksifiye eder. ${ }^{[42]}$

\section{NSAi ILAÇLARIN KULLANIM ILKELERi}

- Tedaviye mümkün olan en düşük dozla başlanıp hasta yanıtı izlenmelidir. Ancak, NSAi ilaçların doz-yanıt eğrisinde tavan etki görülür. Yani, analjezik etkinlik bir noktadan sonra artış göstermezken, yan etkiler artmaya devam eder.

- Birden fazla NSAi ilacın kombine kullanımı, ek yarar sağlamazken toksisiteleri artar. Ancak, NSAi ilaçlar ile asetaminofen kombinasyonunun sinerjistik analjezik etkinlik sağladığı gösterilmiştir. Özellikle bu iki ilacın düşük dozlarda kombine edilmesiyle, yan etki insidansında da azalma gözlenebilir. ${ }^{[7]}$

- Opioid ilaçların, NSAi ilaçlar veya asetaminofen ile kombinasyonunda da, hem nöropatik hem de inflamatuvar ağrı tedavisinde sinerjistik etkiler sağlandığı bildirilmiştir. Benzer şekilde, bu kombinasyonlar sayesinde düşük doz ilaç kullanımı sağlanarak yan etki insidansında azalma elde edilebilir. ${ }^{[43]}$

- NSAi ilaçlara yanıt kişiden kişiye değişebilir. Bir NSAi ilaçtan yarar sağlanamadığında diğer bir NSAí ilaç denenebilir.

- Uzun süreli kullanımlarda hasta, aralıklara kan üre azotu, kreatinin, karaciğer enzimleri, gaitada gizli kan ile takip edilmelidir.

- Hastalar mutlaka kardiyovasküler hastalık, kanama bozuklukları, böbrek hastalıkları, astım, alerji öyküsü, kullanılan diğer ilaçlar açısından dikkatle sorgulanmalıdır.

- Gebelerde (aseteminofen dışında) kullanımından kaçınılmalıdır. ${ }^{[7,44]}$

\section{NSAI ILAÇLARIN KRONIK BOYUN VE BEL AĞRISINDA ETKINLIĞi}

Kronik bel ağrısında NSAi ilaçların etkinliğinin değerlendirildiği güncel Cochrane derlemesinde; NSAi ilaçlar plasebodan daha etkili bulunmuş, 56 günlük (IQR: 13-91) takip sonucunda 100 puanlık görsel analog skalada ortalama 7 puanlık iyileşme saptanmıştır. Ancak, kanıt düzeyi düşük kalitede bulunmuştur. Engelliliği azaltmada da, benzer şekilde, NSAi ilaçlar plasebodan üstün saptamıştır. Yan etki 
profili açısından plasebo ile anlamlı fark saptanmasa da, küçük örneklem büyüklükleri ve kısa takip süreleri nedeniyle, yan etkilerin gerçekte olduğundan az göründüğü yorumu yapılmıştır. NSAi ilaçların uzun dönem güvenirlikleri hakkında kesin kanıya varılamadığı belirtilmiştir. Hem klasik NSAi ilaçlar arasında hem de klasik NSAi ilaçlar ile COX2 selektif ilaçların karşılaştırmasında, herhangi bir etkinlik farkı saptanmamıştır. Derlemeye dahil edilen bir çalışmada ise, asetaminofen ile diflunisal arasında analjezik etkinlik açısından fark bulunmamıştır. ${ }^{[45]}$ Kronik bel boyun ağrılarının, her zaman nonspesifik karakterde olmayıp nöropatik ağrı komponentinin de eşlik edebildiği bilinmektedir. Nöropatik ağrıda oral NSAi ilaçların etkinliğinin değerlendirildiği son Cochrane derlemesinde; nöropatik komponentin olduğu kronik bel ağrısında, oral NSAi ilaçların ağrıyı azaltmada hiç bir anlamlı etkisi olmadığı belirtilmiştir. ${ }^{[46]}$

Sonuç olarak; asetaminofen ve NSAi ilaçlar, kronik boyun ve bel ağrılarının tedavisinde kısa süreli ve ilk basamak olarak kullanılabilir. Ancak, özellikle ağrının nöropatik komponentinin olduğu durumlarda etkisiz olmaları, uzun dönem güvenirliklerinin az olması ve yan etki profilleri nedeniyle, bu alanda kullanım alanı kısıtlı kalmaktadır. Opioid ilaçlar ile düşük dozlarda kombinasyonları ise, sinerjistik etki göstermeleri ve yan etkilerden kaçınmak adına, alternatif olarak görülmektedir.

\section{KAYNAKLAR}

1. Kuijpers $T$, van Middelkoop $M$, Rubinstein $S$, Ostelo $R$, Verhagen A, Koes B, van Tulder MW. A systematic review on the effectiveness of pharmacological interventions for chronic non-specific low-back pain. Eur Spine J 2011;20(1):40-50. Crossref

2. Vogt MT, Kwoh CK, Cope DK, Osial TA, Culyba M, Starz TW. Analgesic usage for low back pain: impact on health care costs and service use. Spine (Phila Pa 1976) 2005;30(9):1075-81.

3. Kroenke K, Krebs EE, Bair MJ. Pharmacotherapy of chronic pain: a synthesis of recommendations from systematic reviews. Gen Hosp Psychiatry 2009;31(3):206-19. Crossref

4. McCarberg B, Gibofsky A. Need to develop new nonsteroidal anti-inflammatory drug formulations. Clin Ther 2012;34(9):1954-63. Crossref

5. Fine M. Quantifying the impact of NSAID-associated adverse events. Am J Manag Care 2013;19(14 Suppl):s267-72.

6. Yentür EA. Nonsteroid antienflamatuar ilaçlar. I. Ağrı Bülteni 2006;1.

7. Miranda HF, Puig MM, Prieto JC, Pinardi G. Synergism between paracetamol and nonsteroidal anti-inflammatory drugs in experimental acute pain. Pain 2006;121(1):22-8.

8. Grosser T, Smyth EM, FitzGerald GA. Anti-Inflammatory, Antipyretic, and Analgesic Agents; Pharmacotherapy of Gout. In: Brunton LL, Chabner BA, Knollmann BC, editors. Goodman and Gilman's Pharmacological Basis of Therapeutics, 12th ed. Mcgraw Hill Medical; 2012. p.959-1004.
9. Melli M, Kayaalp SO. Non-steroidal antiinflamatuar ilaçlar. In: Kayaalp SO. editör. Rasyonel Tedavi Yönünden Tıbbi Farmakoloji, 11. baskı. Ankara: Hacettepe-Taş 2005; p.837-70.

10. Katz JA. COX-2 inhibition: what we learned -a controversial update on safety data. Pain Med 2013;14 Suppl 1:S29-34. Crossref

11. Ayoub SS, Colville-Nash PR, Willoughby DA, Botting RM. The involvement of a cyclooxygenase 1 gene-derived protein in the antinociceptive action of paracetamol in mice. Eur J Pharmacol 2006;538(1-3):57-65.

12. Graham GG, Robins S-A, Bryant KJ, Scott KF. Inhibition of prostaglandin synthesis in intact cells by paracetamol (acetaminophen). InflammoPharmacology 2001;9(1):13142. Crossref

13. Bannwarth B, Demotes-Mainard F, Schaeverbeke T, Dehais J. Where are peripheral analgesics acting? Ann Rheum Dis 1993;52(1):1.

14. Birrell GJ, McQueen DS, Iggo A, Coleman RA, Grubb BD. PGI2-induced activation and sensitization of articular mechanonociceptors. Neurosci Lett 1991;124(1):5-8.

15. Steiner AA, Li S, Llanos-Q J, Blatteis C. Differential inhibition by nimesulide of the early and late phases of intravenousand intracerebroventricular-LPS-induced fever in guinea pigs. Neuroimmunomodulation 2002;9(5):263-75.

16. Ito S, Okuda-Ashitaka E, Minami T. Central and peripheral roles of prostaglandins in pain and their interactions with novel neuropeptides nociceptin and nocistatin. Neurosci Res 2001;41(4):299-332.

17. Furst DE, Manning DC. Future directions in pain management. Clin Exp Rheumatol 2000;19(6 Suppl 25):S71-6.

18. Patrono C. Aspirin as an antiplatelet drug. N Engl J Med 1994;330(18):1287-94. Crossref

19. Griffin MR1, Piper JM, Daugherty JR, Snowden M, Ray WA. Nonsteroidal antiinflammatory drug use and increased risk for peptic ulcer disease in elderly persons. Ann Intern Med 1991;114(4):257-63.

20. Papatheodoridis GV, Sougioultzis S, Archimandritis AJ. Effects of Helicobacter pylori and nonsteroidal anti-inflammatory drugs on peptic ulcer disease: a systematic review. Clin Gastroenterol Hepatol 2006;4(2):130-42.

21. Malfertheiner P, Megraud F, O'Morain C, Bazzoli F, El-Omar E, Graham D, Hunt R, Rokkas T, Vakil N, Kuipers EJ. Current concepts in the management of Helicobacter pylori infection: the Maastricht III Consensus Report. Gut 2007;56(6):772-81.

22. Pugh AJ, Barve AJ, Falkner K, Patel M, McClain CJ. Druginduced hepatotoxicity or drug-induced liver injury. Clin Liver Dis 2009;13(2):277-94. Crossref

23. Soni P, Shell B, Cawkwell G, Li C, Ma H. The hepatic safety and tolerability of the cyclooxygenase- 2 selective NSAID celecoxib: pooled analysis of 41 randomized controlled trials. Curr Med Res Opin 2009;25(8):1841-51. Crossref

24. Perazella MA. Drug-induced renal failure: update on new medications and unique mechanisms of nephrotoxicity. Am J Med Sci 2003;325(6):349-62.

25. Kleinknecht $D$. Interstitial nephritis, the nephrotic syndrome, and chronic renal failure secondary to nonsteroidal antiinflammatory drugs. Semin Nephrol 1995;15:214-27.

26. Goodwin SD, Glenny RW. Nonsteroidal Anti-inflammatory Drug-Associated Pulmonary Infiltrates With Eosinophilia: Review of the Literature and Food and Drug Administration Adverse Drug Reaction Reports. Arch Intern Med 1992;152(7):1521-4. 
27. Mockenhaupt M, Kelly JP, Kaufman D, Stern RS, SCAR Study Group. The risk of Stevens-Johnson syndrome and toxic epidermal necrolysis associated with nonsteroidal antiinflammatory drugs: a multinational perspective. J Rheumatol 2003;30(10):2234-40.

28. Hoppmann RA, Peden JG, Ober SK. Central nervous system side effects of nonsteroidal anti-inflammatory drugs: aseptic meningitis, psychosis, and cognitive dysfunction. Arch Intern Med 1991;151(7):1309-13.

29. Coxib and traditional NSAID Trialists' (CNT) Collaboration, Bhala N, Emberson J, Merhi A, Abramson $\mathrm{S}$, Arber N, Baron JA, Bombardier C, Cannon C, Farkouh ME, FitzGerald GA, Goss P, Halls H, Hawk E, Hawkey C, Hennekens C, Hochberg M, Holland LE, Kearney PM, Laine L, Lanas A, Lance P, Laupacis A, Oates J, Patrono C, Schnitzer TJ, Solomon S, Tugwell P, Wilson K, Wittes J, Baigent C. Vascular and upper gastrointestinal effects of non-steroidal anti-inflammatory drugs: meta-analyses of individual participant data from randomised trials. Lancet (London, England) 2013;382(9894):769-79. Crossref

30. FitzGerald GA. Cardiovascular pharmacology of nonselective nonsteroidal anti-inflammatory drugs and coxibs: clinical considerations. Am J Cardiol 2002;89(6A):26D-32D.

31. Solomon DH, Schneeweiss S, Levin R, Avorn J. Relationship between COX-2 specific inhibitors and hypertension. Hypertension 2004;44(2):140-5.

32. Solomon $\mathrm{DH}$. Selective cyclooxygenase 2 inhibitors and cardiovascular events. Arthritis Rheum 2005;52(7):1968-78.

33. Björkman R. Central antinociceptive effects of non-steroidal anti-inflammatory drugs and paracetamol. Experimental studies in the rat. Acta Anaesthesiol Scand Suppl 1994;103:1-44.

34. Bujalska M. Effect of nitric oxide synthase inhibition on antinociceptive action of different doses of acetaminophen. Pol J Pharmacol 2004;56(5):605-10.

35. Graham GG, Scott KF. Mechanism of action of paracetamol. Am J Ther 2005;12(1):46-55.
36. Raffa RB, Walker EA, Sterious SN. Opioid receptors and acetaminophen (paracetamol). Eur J Pharmacol 2004;503(1-3):209-10.

37. Pickering G, Esteve V, Loriot MA, Eschalier A, Dubray C. Acetaminophen reinforces descending inhibitory pain pathways. Clin Pharmacol Ther 2008;84(1):47-51.

38. Boutaud O, Aronoff DM, Richardson JH, Marnett LJ, Oates JA. Determinants of the cellular specificity of acetaminophen as an inhibitor of prostaglandin $\mathrm{H}(2)$ synthases. Proc Natl Acad Sci U S A 2002;99(10):7130-5.

39. Aronoff DM, Oates JA, Boutaud O. New insights into the mechanism of action of acetaminophen: Its clinical pharmacologic characteristics reflect its inhibition of the two prostaglandin $\mathrm{H} 2$ synthases. Clin Pharmacol Ther 2006;79(1):9-19.

40. Chandrasekharan NV, Dai H, Roos KL, Evanson NK, Tomsik J, Elton TS, Simmons DL. COX-3, a cyclooxygenase- 1 variant inhibited by acetaminophen and other analgesic/antipyretic drugs: cloning, structure, and expression. Proc Natl Acad Sci U S A 2002;99(21):13926-31.

41. Illkaya F, Yilmaz MZ, Karakuş O. Parasetamol ve Siklooksijenaz Enzim İnhibisyonu. J Exp Clin Med 2013;30:9-14.

42. Heard KJ. Acetylcysteine for acetaminophen poisoning. $\mathrm{N}$ Engl J Med 2008;359(3):285-92. Crossref

43. Shinozaki T, Yamada T, Nonaka T, Yamamoto T. Acetaminophen and non-steroidal anti-inflammatory drugs interact with morphine and tramadol analgesia for the treatment of neuropathic pain in rats. J Anesth 2015;29(3):386-95. Crossref

44. Katz JA. Nonsteroidal anti-inflammatory analgesics. In: Raj PP, editor. Practical Management of Pain, 3rd ed. St Louis; 2000. p.477-88.

45. Enthoven WTM, Roelofs PDDM, Deyo RA, van Tulder MW, Koes BW. Non-steroidal anti-inflammatory drugs for chronic low back pain. The Cochrane Library; 2016.

46. Moore RA, Chi CC, Wiffen PJ, Derry S, Rice AS. Oral nonsteroidal anti-inflammatory drugs for neuropathic pain. Cochrane Database Syst Rev 2015;(10):CD010902. Crossref 